\title{
PENGARUH PEMBERIAN DOLOMIT TERHADAP BEBERAPA SIFAT KIMIA TANAH GAMBUT DAN PERTUMBUHAN SERTA HASIL TANAMAN BAWANG MERAH (Allium ascalonicum L)
}

\author{
Farah Ilham*, Teguh Budi Prasetyo, Sandra Prima \\ Prodi Ilmu Tanah, Fakultas Pertanian, Universitas Andalas, Padang \\ *email: farahilham28@gmail.com
}

\begin{abstract}
This research was aimed to study the effect of dolomite on chemical properties of peat soil and as well as on growth and yield of onion. The research was in form of pot experiment having 5 treatments $\left(0\right.$ ton dolomite $\mathrm{Ha}^{-1} ; 2.5$ ton dolomite $\mathrm{Ha}^{-1} ; 5$ ton dolomite $\mathrm{Ha}^{-1} ; 7.5$ ton dolomite $\mathrm{Ha}^{-1} ; 10$ ton dolomite $\mathrm{Ha}^{-1}$ ) and 3 replications which were allocated in Completely Randomized Design. Parameters analyzed were $\mathrm{pH} \mathrm{H}_{2} \mathrm{O}$, available sulphur, available phosphorus, CEC, and exchangeable cations, as well plant height, plant dry weight, sulphur uptake, and diameter of tubers. Data resulted were analyzed the variance using F-test at 5\% level of significance and then it was continued using Duncan New's Multiple Range Test (DNMRT) at 5\% level if F-test > F-table. The results showed that 10 ton dolomite $\mathrm{Ha}^{-1}$ was the optimum dose to improve chemical characteristics of peat soils. It increased $\mathrm{pH} \mathrm{H}_{2} \mathrm{O}$ by 1.16 unit, sulphur uptake by $0.005 \%$, available phosphorus by $5.7 \mathrm{ppm}$, CEC by $9.67 \mathrm{Cmol} \mathrm{Kg}^{-1}$ and exchangeable $\mathrm{K}$ by $0.09 \mathrm{Cmol}$

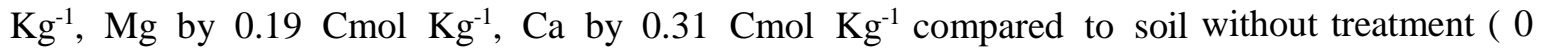
ton $\mathrm{Ha}^{-1}$ ). It also increased production of onion, especially plant height by $22.63 \mathrm{~cm}$, plant fresh weight by $43.14 \mathrm{~g}$ and dry weight by $2.89 \mathrm{~g}$, tuber fresh weight by $21.92 \mathrm{~g}$, and dry weight by $2.89 \mathrm{~g}$, sulphur uptake by $0.03 \%$, and diameter of tubers from none to be $2.00 \mathrm{~cm}$ compared to soil without treatment.
\end{abstract}

Key words : dolomite, peat soils, onion, soil chemical characteristics

(C) 2019 Farah Ilham, Teguh Budi Prasetyo, Sandra Prima

\section{PENDAHULUAN}

Indonesia memiliki lahan gambut terluas diantara negara tropis, yaitu sekitar 21 juta $\mathrm{Ha}$ atau $10,80 \%$ dari luas daratan Indonesia. Lahan rawa gambut sebagian besar terdapat di empat pulau besar yaitu di Sumatera 35\%, Kalimantan 32\% Papua 30\% dan sebagian kecil ada di Sulawesi, Halmahera dan Seram 3\% (Radjagukguk, 1991). Sumatera Barat memiliki lahan gambut seluas 436.000 Ha yang tersebar di Kinali (Kabupaten Pasaman), Dataran Anai (Pariaman), dan Silaut (Kabupaten Pesisir Selatan) (Luki dan Abbas, 1990).
Gambut yang ada di Indonesia sekarang ini terbentuk dalam waktu lebih dari 5000 tahun (Hardjowigeno, 1989) dan merupakan jenis gambut tropis yang terbentuk sebagai hasil proses penumpukan sisa tumbuhan rawa seperti berbagai macam jenis rumput, paku-pakuan, bakau, pandan, pinang, serta tumbuhan rawa lainnya (Meene, 1984). Karena tempat tumbuh dan tertimbunnya sisa tumbuhan tersebut selalu lembab dan tergenang air serta sirkulasi oksigen $\left(\mathrm{O}_{2}\right)$ yang kurang bagus, maka proses humifikasi oleh bakteri tidak berjalan dengan sempurna. Sebagai akibatnya sebagian serat-serat tumbuhan masih 
terlihat jelas dan sangat mempengaruhi perilaku dari tanah gambut yang bersangkutan. Faktor pembatas yang menghambat pertumbuhan tanaman di lahan gambut yaitu : (1) ketebalan gambut dan taraf dekomposisi bahan organik, (2) status hara makro dan mikro yang rendah, (3) kemasaman tanah dan kandungan asam-asam organik meracun tinggi, dan (4) tata air yang buruk (Prasetyo, 2003)

Sajarwan (2007) mengemukakan bahwa pengembangan lahan gambut yang digunakan sebagai lahan pertanian memiliki beberapa kendala, baik fisik, kimia dan biologis. Kendala utama tanah gambut adalah memiliki sifat kering tak balik (irreversible drying) apabila mengalami kekeringan, sehingga tanah tersebut tidak dapat dijadikan sebagai bahan koloid organik. Tanah gambut yang telah mengalami kekeringan, koloidnya akan rusak dan tidak bisa mendukung ketahanan tanah gambut tersebut. Hal ini dikarenakan, tanah akan memiliki sifat seperti pasir yang tidak dapat menahan air, dimana koloid berperan penting dalam mengikat air. Selain itu, hara makro dan mikro pada tanah gambut sangat sedikit tersedia, tingkat kemasaman yang tinggi dengan nilai $\mathrm{pH} 4-5$, serta rendahnya kejenuhan basa berkisar 6$10 \%$. Tanah gambut memiliki kadar air yang tinggi karena selalu tergenang, hal ini menyebabkan bobot volume menjadi rendah, tanah menjadi lembek dan daya menahan bebannya juga rendah.

Salah satu cara untuk mengatasi kekurangan unsur hara makro dan mikro yang pada tanah gambut adalah dengan pengapuran. Pengapuran adalah suatu teknologi pemberian kapur kedalam tanah, yang dimasudkan untuk memperbaiki sifat-sifat kimia, fisika dan biologi tanah (Soepardi, 1986). Menurut Hardjowigeno (1995), umumnya bahan kapur untuk pertanian adalah berupa kalsiun karbonat $\left(\mathrm{CaCO}_{3}\right)$, beberapa berupa dolomit $\left(\mathrm{CaMg}\left(\mathrm{CO}_{3}\right) 2\right)$, dan hanya sedikit berupa $\mathrm{CaO}$ (Kalsium Oksida) atau $\mathrm{Ca}(\mathrm{OH}) 2$ (Kalsium Hidroksida). Dolomit $\left[\mathrm{CaMg}\left(\mathrm{CO}_{3}\right)_{2}\right]$ mengandung $\mathrm{Ca}^{2+}: 21,73 \%$, $\mathrm{Mg}^{2+}: 13,18 \%, \mathrm{C}: 13,03 \%$, O: $52,06 \%, \mathrm{CaO}:$
30,40\%, MgO: 21,70\%, CO2: 47,90\%. Selain itu dolomit banyak digunakan karena relatif murah dan mudah didapat (Djuhariningrum et al., 2004). Disamping itu bahan tersebut dapat memperbaiki sifat fisik tanah dan kimia dengan tidak meninggalkan residu yang merugikan tanah (Safuan, 2002). Pengaruh kapur pada tanah gambut dapat memperbaiki $\mathrm{pH}$ tanah, kejenuhan basa (KB), meningkatkan unsur kalsium $(\mathrm{Ca})$ dan Magnesium $(\mathrm{Mg})$ serta mengurangi ketersedian senyawa-senyawa organik beracun.

Pemanfaatan lahan gambut sebagai areal tanam tanaman bawang merah memerlukan beberapa perlakuan untuk meningkatkan produktivitasnya. Agar diperoleh kondisi yang optimal bagi pertumbuhan tanaman tersebut, maka dapat dilakukan dengan cara diberikan bahan amelioran dan tata airnya diatur agar tidak terjadi penggenangan. Salah satu bahan amelioran yang dapat digunakan yaitu, dolomit yang memiliki tingkat kebasaan yang sangat tinggi dan masuk kritera sangat basa. Selain itu, dolomit mengandung $\mathrm{Ca}$ yang sangat tinggi dapat meningkatkan $\mathrm{pH}$, dimana akan menambah ketersediaan unsur hara, menghilangkan senyawa yang beracun, meningkatkan kegiatan jasad renik dalam tanah dan memperbaiki sifat fisik tanah.

Hasil penelitian yang telah dilaksanakan oleh Kosasih (1986) cit Nurhaida (1988), pemberian dolomit pada tanaman kedelai yang ditanami pada tanah gambut dapat meningkatkan tinggi tanaman, diameter batang, jumlah dan bintil akar serta berat biji tanaman kedelai sangat nyata. Produksi maksimum biji kedelai pada tanah gambut diperoleh pemberian kapur dolomit sebanyak $51 \mathrm{~g} /$ polybag setara dengan 8,6 ton kapur/Ha sebesar 18,04 g biji kedelai/polybag. Serta hasil penelitian yang telah dilaksanakan oleh Saijo (2012), produksi maksimum jumlah buah tomat serta berat buah tomat pertaman dengan pemberian dolomit sebanyak $7,2 \mathrm{Kg} /$ polybag setara dengan 6 ton/Ha sebesar 7,85 buah tomat pertanaman serta $8,44 \mathrm{~g}$ berat tanaman tomat pertanaman. Berdasarkan penelitian yang telah dilaksanakan oleh Kosasih (1989) serta 
Saijo (2012) maka didapatkan acuan dosis untuk pemberian dosis dolomit sebanyak 2,5 ton/Ha; 5 ton/Ha; 7,5 ton/Ha; dan 10 ton $/ \mathrm{Ha}$ terhadap tanah gambut yang digunakan sebagai media tanam bawang merah.

Bawang merah (Allium ascalonicum $\mathrm{L}$ ) family Liliaceae yang berasal dari Asia Tengah merupakan salah satu komoditas hortikultura yang sering digunakan sebagai bumbu masakan. Badan Pusat Statistik (BPS) dan Direktorat Jenderal Hortikurtura (DJH) menyebutkan bahwa produksi bawang merah di Indonesia dari tahun 2006-2010 selalu mengalami peningkatan sebesar 799,93 ton; 802,81 ton; 853,62 ton; 965,12 ton; $1.048,93$ ton. Akan tetapi, sepanjang tahun 2010 impor bawang merah di Indonesia tercatat sebesar 73,86 ton dan dalam tiga bulan pertama tahun 2011, impor bawang merah di Indonesia mencapai 85,73 ton. Hal ini membuktikan bahwa kebutuhan akan bawang merah di dalam negeri masih tinggi dibandingkan ketersediaannya. Tanaman ini memerlukan struktur tanah remah, drainase dan aerasi baik, mengandung bahan organik yang cukup yaitu $>2,5 \%$, dan reaksi tanah agak masam sampai mendekati netral $(6,0-6,8)$. $\mathrm{pH}$ tanah 5,5 - 7,0 masih dapat digunakan untuk penanaman bawang merah. Jenis tanah yang cocok untuk budidayanya adalah tanah Alluvial, Latosol atau Andosol ber- $\mathrm{pH}$ antara 5,5 - 7,0 (Deptan, 2007). Bawang merah dapat tumbuh di dataran rendah sampai dataran tinggi $(0-1000 \mathrm{~m} \mathrm{dpl})$, namun pertumbuhan optimal pada ketinggian $0-400$ $\mathrm{m}$ dpl. Bawang merah membutuhkan unsur Nitrogen (N), Phosfor (P), Kalium (K) serta Sulfur (S). Sulfur dibutuhkan tanaman dalam penyusun protein, beberapa hormon tanaman, vitamin dan enzim. Didalam sulfur mengandung minyak mustard yang membuat bawang merah mengeluarkan bau dan rasa yang khas (Bancin, 2016). Tujuan penelitian adalah untuk mempelajari pengaruh dari pemberian dolomit terhadap perubahan sifat kimia tanah gambut Anai - Lubuk Alung, Padang Pariaman; dan mempelajari

https://doi.org/10.25077/jsolum.16.1.29-39.2019 pengaruh dari pemberian dolomit terhadap pertumbuhan dan produksi bawang merah.

\section{BAHAN DAN METODA}

Penelitian dilaksanakan dari bulan Mei sampai September 2016, di rumah kawat Fakultas Pertanian, Universitas Andalas Padang dan Laboratorium Jurusan Tanah Fakultas Pertanian. Bahan yang digunakan pada penelitian adalah kapur yang berjenis dolomit $\left(\mathrm{CaMg}\left(\mathrm{CO}_{3}\right) 2\right)$. Tanah yang digunakan yaitu tanah gambut yang berasal dari daerah Anai-Lubuk Alung, Kabupaten Padang Pariaman, Sumatera Barat. Umbi bawang merah yang digunakan bervaritas Bima yang berasal dari Brebes.

Penelitian ini menggunakan Rancangan Acak Lengkap dengan 5 perlakuan dosis kapur dengan 3 kali ulangan. Taraf pemberian pelakuan dosis berdasarkan penelitian Kosasih (1986), bahwa pemberian kapur sebanyak 8,6 ton/Ha setara 51 g/polybag dapat menghasilkan biji kedelai sebesar 18,04 g biji kedelai/polybag. Maka dari penilitian Kosasih (1986), didapatkan dosis dolomit yang digunakan pada penelitian, yaitu

$\mathrm{K}_{\mathrm{O}}=$ Tanpa Kapur Dolomit 0 ton $\mathrm{Ha}^{-1}(0 \mathrm{~g} / 2$ $\mathrm{kg}$ tanah)

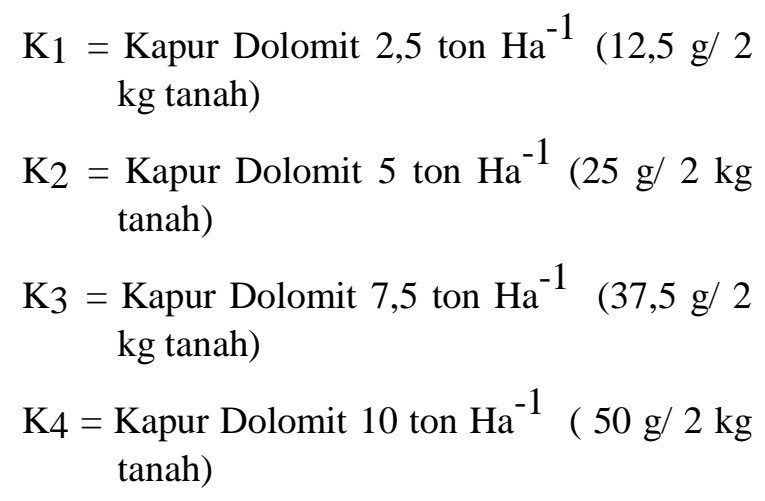
$\mathrm{K} 3=$ Kapur Dolomit 7,5 ton $\mathrm{Ha}^{-1} \quad(37,5 \mathrm{~g} / 2$ $\mathrm{kg}$ tanah)

Data hasil pengamatan dianalisis secara statistik dengan uji $\mathrm{F}$ dan jika uji $\mathrm{F}$ hitung lebih besar dari $\mathrm{F}$ tabel $5 \%$ maka dilanjutkan dengan uji lanjut Duncan's New Multiple Range Test (DNMRT) pada taraf nyata $5 \%$.

Tanah gambut diambil secara komposit dengan kedalaman $0-20 \mathrm{~cm}$. Tanah dibersihkan dari akar-akar tanaman dan 
kotoran yang ada kemudian dikeringanginkan sampai keadaan lembab dan diayak. Selanjutnya tanah ditimbang untuk masingmasing polybag sebanyak $2 \mathrm{~kg}$ setara berat kering mutlak lalu dicampurkan dengan dolomit secara merata sesuai dengan dosis perlakuan dan diinkubasi selama 15 hari.

Penanaman dilakukan dengan menanam umbi bawang merah sebanyak 2 umbi/polybag. Pemberian pupuk dasar berdasarkan jarak tanam $15 \mathrm{~cm} \quad$ x $20 \mathrm{~cm}$ dengan jumlah tanaman sebanyak 333.333 rumpun/Ha adalah sebagai berikut pupuk urea dengan dosis $300 \mathrm{~kg} / \mathrm{Ha} \quad(0,9 \mathrm{~g} / \mathrm{tanaman})$ dan $\mathrm{KCl}$ dengan dosis $100 \mathrm{~kg} / \mathrm{Ha}(0,3$ g/tanaman) sebanyak 3 kali pada saat tanaman berumur 15, 30, 45 hari setelah tanam masingmasing $1 / 3$ dari dosis yang direkomendasikan. Pemberian pupuk SP-36 dengan dosis $180 \mathrm{~kg} / \mathrm{Ha}(0,54 \mathrm{~g} /$ tanaman $)$ sebanyak 1 kali pada awal tanam.

Analisis tanah awal dan setelah inkubasi di laboratorium meliputi: analisis $\mathrm{pH}$ $\mathrm{H}_{2} \mathrm{O}$ dengan metode Elektrometrik, $\mathrm{P}$ tersedia metode Bray II di ukur dengan Spektrofotometer, dan KTK, Mg-dd, Ca-dd, K- dd dengan metoda pencucian Ammonium Asetat (NH4OAc) $1 \mathrm{~N} \mathrm{pH} 4$ diukur dengan AAS serta pengukuran $\mathrm{S}$ dengan metoda pengabunan basah dengan $\mathrm{HNO}_{3}$ dan $\mathrm{HClO}_{4}$.

Pengamatan tanaman berupa pengamatan tinggi tanaman yang dilakukan pada hari ke 15, 25, 35, 45 HST, ukuran umbi, berat tanaman, berat umbi, hara $\mathrm{S}$ tanaman. Data yang diperoleh diolah secara statistik dengan analisis ragam menurut Rancangan Acak Lengkap ( RAL ), dan untuk perlakuan berpengaruh nyata dilanjutkan dengan uji lanjut DNMRT pada taraf $5 \%$.

\section{HASIL DAN PEMBAHASAN}

Analisis Tanah Sebelum Inkubasi

Berdasarkan hasil analisis tanah awal (Tabel 1) menunjukkan bahwa $\mathrm{pH} \quad 3,58$ tergolong sangat masam. Menurut Jones (1984), nilai $\mathrm{pH}$ rendah itu disebabkan oleh asam-asam organik dan ion $\mathrm{H}^{+}$dapat ditukar (H-dd) yang tinggi terkandung dalam tanah gambut.

Tabel 1. Hasil analisis tanah awal sebelum inkubasi terhadap beberapa sifat kimia tanah gambut daerah Anai - Lubuk Alung, Kabupaten Pariaman, Sumatera Barat.

\begin{tabular}{|c|c|c|c|c|}
\hline No & Jenis Analisis & Satuan & Nilai & Kriteria* \\
\hline 1 & $\mathrm{pH} \mathrm{H} \mathrm{H}_{2} \mathrm{O}(1: 5)$ & - & 3,58 & Sangat Masam \\
\hline 2 & S & $\%$ & 0,01 & - \\
\hline 3 & P-tersedia & Ppm & 7,50 & Sangat Rendah \\
\hline 4 & KTK & $\mathrm{me} / 100 \mathrm{~g}$ & 60,35 & Sangat Tinggi \\
\hline 5 & K-dd & $\mathrm{me} / 100 \mathrm{~g}$ & 0,21 & Rendah \\
\hline 6 & Ca-dd & $\mathrm{me} / 100 \mathrm{~g}$ & 0,64 & Rendah \\
\hline 7 & Mg-dd & $\mathrm{me} / 100 \mathrm{~g}$ & 0,64 & Rendah \\
\hline
\end{tabular}

*Sumber : Hardjowigeno (1995)

Nilai Ca-dd dan Mg-dd yang diperoleh secara berturut-turut yaitu $0,64 \mathrm{me} / 100 \mathrm{~g}$ (rendah) dan $0,64 \mathrm{me} / 100 \mathrm{~g}$ (rendah). Sedangkan nilai K-dd yang diperoleh yaitu $0,21 \mathrm{me} / 100 \mathrm{~g}$ (rendah). Dari hasil yang diperoleh dapat dilihat bahwa tanah gambut memiliki kandungan basa- basa yang rendah dikarenakan bahan pembentuk tanah gambut berasal dari vegetasi alami (sisa tumbuhan dan hewan) serta tanah gambut terbentuk diatas 
tanah miskin hara atau hanya mendapatkan hara dari air hujan. Vegetasi alami (rerumputan, sisa-sisa pohon dan lumut) tersebut memiliki kandungan basa yang rendah, sehingga apabila mengalami pelapukan akan menghasilkan asam-asam organik serta menyebabkan kandungan basa pada tanah gambut juga rendah.

Nilai KTK tanah gambut 60,35 termasuk sangat tinggi. Menurut Tim Fakultas Pertanian IPB (1986), tanah gambut dengan ciri KTK sangat tinggi, tetapi persentase KB sangat rendah, akan menyulitkan penyerapan hara, terutama basa-basa yang diperlukan oleh tanaman. KTK yang sangat tinggi disebabkan oleh banyaknya kandungan asam-asam organik pada tanah tersebut. Bahan - bahan organik pada tanah gambut pada umumnya mengandung lignin dan sedikit mengandung selulosa, hemiselulosa, dan protein (Sabiham 1993 cit Prasetyo, 1996).

Kandungan P-tersedia di dalam tanah gambut termasuk rendah $(7,50 \mathrm{ppm})$, disebabkan unsur fosfor $(\mathrm{P})$ pada tanah gambut sebagian besar dijumpai dalam bentuk Porganik, yang selanjutnya akan mengalami proses mineralisasi menjadi P-anorganik oleh jasad mikro. Fraksi P-organik diperkirakan mengandung $2 \% \mathrm{P}$ sebagai asam nukleat, $1 \%$ sebagai fosfolipid dan $35 \%$ inositol fosfat (Stevenson, 1984).

Kadar $\mathrm{S}$ termasuk rendah $(0,01 \%)$ karena $\mathrm{S}$ total dalam tanah berkisar $(0,05-0,4$ $\%)$. Total S dalam tanah bervariasi, nilai yang lebih tinggi dapat ditemukan pada tanah-tanah bermasalah seperti tanah salin dan tanah sulfat masam (Takkar, 1988). S dalam tanah terdapat dalam bentuk organik dan inorganik. Bentuk $\mathrm{S}$ anorganik penting ada dalam tanah sebab sebagian besar $\mathrm{S}$ diambil oleh tanaman dalam bentuk sulfat $\left(\mathrm{SO}_{4}{ }^{2-}\right)$, begitu juga dalam bentuk $\mathrm{S}$ organik juga penting dalam tanah karena dapat meningkatkan total $\mathrm{S}$ tanah (Prasad dan Power, 1997). Kadar S dalam tanah dipengaruhi oleh penambahan $\mathrm{S}$ dari bahan organik, air irigasi, udara, pupuk dan pestisida.

\section{Analisis Tanah Sesudah Inkubasi}

Tabel 1 menunjukkan bahwa terjadi peningkatan nilai $\mathrm{pH}$ tanah gambut seiring dengan dilakukannya penambahan takaran dolomit sebesar 2,5 ton/Ha; 5 ton/Ha; 7,5 ton/Ha dan 10 ton/Ha. Jika dibandingkan dengan tanpa perlakuan $(0$ ton/Ha) peningkatan yang terjadi sebesar 0,$4 ; 0,7 ; 1,03$; 1,16. Peningkatan $\mathrm{pH}$ tanah gambut ini, diduga karena dolomit yang terhidrolisis akan menyumbangkan ion $\mathrm{OH}^{-}$yang dapat menetralkan ion $\mathrm{H}^{+}$dari larutan tanah sehingga $\mathrm{pH}$ tanah meningkat. Semakin tinggi takaran yang diberikan maka semakin banyak ion $\mathrm{OH}^{-}$dalam larutan tanah, $\mathrm{pH}$ semakin meningkat. Kenaikan $\mathrm{pH}$ terjadi setelah perlakuan karena diduga pengaruh dolomit, sesuai dengan reaksi hidrolisis sebagai berikut (Soepardi, 1983) :

\section{$\mathrm{CaMg}\left(\mathrm{CO}_{3}\right) 2+\mathrm{H} 2 \mathrm{O}-\mathrm{a}^{2+}+\mathrm{Mg}^{2+}+\mathrm{HCO}_{3}{ }^{-}+2 \mathrm{OH}^{-}$ $2 \mathrm{OH}^{-}+\mathrm{H}^{+}-\mathrm{H}_{2} \mathrm{O}$}

Reaksi yang berlangsung diatas menunjukkan bahwa anion-anion $\mathrm{HCO}_{3}^{-}$dan OHyang dihasilkan diduga dapat menetralkan $\mathrm{H}^{+}$dalam larutan tanah dan $\mathrm{pH}$ larutan tanah naik (Soepardi, 1983). Peningkatan $\mathrm{pH}$ ini dipengaruhi oleh kandungan $\mathrm{Ca}^{2+}$ dan $\mathrm{Mg}^{2+}$ yang terdapat dalam dolomit. Peningkatan $\mathrm{pH}$ pada penelitian ini belum mencapai batas maksimal yang dibutuhkan untuk pertumbuhan dan hasil tanaman bawang merah, yang mana syarat tumbuh tanaman bawang merah berkisar pH 5,5 - 7,0. Maka dari itu, perlu meningkatkan pemberian dosis dolomit pada tanah gambut agar tanaman bawang merah dapat tumbuh dengan baik.

Tabel 2. Pengaruh pemberian dolomit terhadap bebrapa ciri kimia tanah gambut daerah Anai - Lubuk Alung, Kabupaten Pariaman, Sumatera Barat. 
e-ISSN 2356-0835

\begin{tabular}{cccccccc}
\hline $\begin{array}{c}\text { Takaran } \\
\text { Dolomit } \\
\text { (ton/Ha) }\end{array}$ & $\begin{array}{c}\mathrm{pH} \\
(\mathrm{H} 2 \mathrm{O})\end{array}$ & $\begin{array}{c}\text { P-tersedia } \\
(\mathrm{ppm})\end{array}$ & $\begin{array}{c}\text { K-dd } \\
(\mathrm{me} / 100 \mathrm{~g})\end{array}$ & $\begin{array}{c}\text { Ca-dd } \\
(\mathrm{me} / 100 \mathrm{~g})\end{array}$ & $\begin{array}{c}\text { Mg-dd } \\
(\mathrm{me} / 100 \mathrm{~g})\end{array}$ & $\begin{array}{c}\mathrm{S} \\
\%\end{array}$ & $\begin{array}{c}\text { KTK } \\
(\mathrm{me} / 100 \mathrm{~g})\end{array}$ \\
\hline 0 & $3,59 \mathrm{a}$ & $7,50 \mathrm{a}$ & 0,21 & $0,64 \mathrm{a}$ & 0,64 & $0,011 \mathrm{a}$ & $60,35 \mathrm{a}$ \\
2,5 & $4,00 \mathrm{~b}$ & $7,80 \mathrm{a}$ & 0,25 & $0,80 \mathrm{~b}$ & 0,67 & $0,012 \mathrm{~b}$ & $64,55 \mathrm{~b}$ \\
5 & $4,29 \mathrm{c}$ & $11,47 \mathrm{~b}$ & 0,28 & $0,81 \mathrm{~b}$ & 0,77 & $0,012 \mathrm{~b}$ & $68,05 \mathrm{c}$ \\
7,5 & $4,63 \mathrm{~d}$ & $11,73 \mathrm{~b}$ & 0,29 & $0,91 \mathrm{~b}$ & 0,77 & $0,014 \mathrm{c}$ & $68,57 \mathrm{c}$ \\
10 & $4,76 \mathrm{~d}$ & $13,20 \mathrm{~b}$ & 0,30 & $0,95 \mathrm{c}$ & 0,83 & $0,016 \mathrm{~d}$ & $70,02 \mathrm{c}$ \\
\hline KK & $3,35 \%$ & $19,72 \%$ & $19,44 \%$ & $12,07 \%$ & 12,58 & $10,13 \%$ & $3,39 \%$ \\
\hline
\end{tabular}

Keterangan : Angka yang diikuti dengan huruf kecil yang sama berbeda tidak nyata pada taraf $5 \%$ uji Duncan (DNMRT)

Nilai P-tersedia gambut terjadi peningkatan seiring dengan dilakukannya penambahan takaran dolomit sebesar 2,5 ton/Ha; 5 ton/Ha; 7,5 ton/Ha dan 10 ton/Ha. Jika dibandingkan dengan tanpa perlakuan (0 ton/Ha) sebesar 0,3 ppm; 3,97 ppm; 4,23 ppm; 5,7 ppm. Dari Tabel 2 terlihat bahwa semakin besar takaran dolomit yang diberikan maka peningkatan P-tersedia semakin tinggi. Hal ini diduga karena semakin tinggi dolomit, maka dekomposisi bahan organik semakin tinggi akibat $\mathrm{pH}, \mathrm{Ca}$ dan $\mathrm{Mg}$ semakin tinggi sehingga aktivitas mikroorganisme meningkat, dengan semakin tingginya dekomposisi bahan organik maka semakin besar P-tersedia yang dihasilkan. Penyataan ini dijelaskan oleh Stevenson (1982) dalam Ali (2007), pemberian bahan amelioran (dolomit) dengan berbagai tingkatan dosis yang berbeda memberikan kecendrungan peningkatan fospat. Peningkatan tersebut terjadi karena pengaruh dekomposisi bahan organik dan kemungkinan adanya aktivitas mikroorganisme baik fungi maupun bakteri.

Berdasarkan hasil analisis sidik ragam menunjukkan bahwa pengaruh pemberian dolomit pada tanah gambut yang sudah dikeringanginkan setelah masa inkubasi selama 2 minggu tidak berbeda nyata terhadap $\mathrm{K}$-dd tanah gambut. terjadi peningkatan nilai K-dd gambut secara angka dengan penambahan takaran dolomit sebesar 2,5 ton/Ha; 5 ton/Ha; 7,5 ton/Ha dan 10 ton/Ha. Jika dibandingkan dengan tanpa perlakuan $(0$ ton/Ha) sebesar 0,04 me/100 g; 0,07 $\mathrm{me} / 100 \mathrm{~g} ; 0,08 \mathrm{me} / 100 \mathrm{~g} ; 0,09 \mathrm{me} / 100 \mathrm{~g}$. Pemberian dolomit tidak memberikan pengaruh nyata terhadap K-dd pada tanah gambut, tetapi secara angka terjadi sedikit peningkatan. Namun hal ini diduga karena dekomposisi $\mathrm{K}$ organik tidak terlalu banyak, sehingga kenaikan tidak terlalu besar.

Tabel 2 menunjukkan bahwa terjadi peningkatan nilai $\mathrm{Ca}$-dd tanah gambut seiring dengan dilakukannya penambahan takaran dolomit sebesar 2,5 ton/Ha; 5 ton/Ha; 7,5 ton/Ha dan 10 ton/Ha. Jika dibandingkan dengan tanpa perlakuan $(0$ ton/Ha) sebesar $0,16 \mathrm{me} / 100 \mathrm{~g} ; 0,17 \mathrm{me} / 100 \mathrm{~g} ; 0,27 \mathrm{me} / 100 \mathrm{~g}$; $0,31 \mathrm{me} / 100 \mathrm{~g}$.

Peningkatan nilai Ca-dd ini diduga karena adanya sumbangan unsur $\mathrm{Ca}$ yang berasal dari dolomit. Berdasarkan analisis yang telah dilakukan dolomit mengandung $\mathrm{CaO}$ sebanyak 35,7 \%. Semakin tinggi dolomit yang diberikan dapat meningkatkan $\mathrm{pH}$ serta aktifitas mikroorganisme mengakibatkan terjadinya dekomposisi bahan organik, hasil dekomposisi bahan organik tersebut yang meningkatkan Ca-dd dalam tanah gambut.

Selanjutnya terjadi peningkatan nilai Mg-dd tanah gambut seiring dengan dilakukan penambahan takaran dolomit sebesar 2,5 ton/Ha; 5 ton/Ha; 7,5 ton/Ha dan 10 ton/Ha. Jika dibandingkan dengan tanpa perlakuan $(0$ ton/Ha) sebesar $0,003 \mathrm{me} / 100 \mathrm{~g}$; $0,13 \mathrm{me} / 100 \mathrm{~g} ; 0,13 \mathrm{me} / 100 \mathrm{~g} ; 0,19 \mathrm{me} / 100 \mathrm{~g}$.

Peningkatan nilai $\mathrm{Mg}$-dd ini karena adanya sumbangan unsur $\mathrm{Mg}$ yang berasal dari dolomit. Berdasarkan analisis yang telah dilakukan dolomit mengandung $\mathrm{MgO}$ sebesar $16,7 \%$. Semakin tinggi dolomit yang diberikan, semakin meningkatnya nilai $\mathrm{pH}$ dan 
menyebabkan aktifitas mikroorganisme semakin meningkat serta terjadinya dekomposisi bahan organik yang semakin tinggi yang menyebabkan meningkatkan kandungan Mg-dd dalam tanah. Pada penelitian yang dilaksanakan oleh Kosasih, (1986) cit Nurhaida, (1988) bahwa pemberian dolomit menaikkan Mg-dd sebesar $0,76 \mathrm{me} / 100 \mathrm{~g}$ dari kontrol sebesar 0,55 $\mathrm{me} / 100 \mathrm{~g}$.

Kadar $\mathrm{S}$ tanah gambut meningkat seiring dengan dilakukannya penambahan takaran dolomit sebesar 2,5 ton/Ha; 5 ton/Ha; 7,5 ton/Ha dan 10 ton/Ha. Jika dibandingkan dengan tanpa perlakuan (0 ton/Ha) peningkatan yang terjadi sebesar $0,001 \% ; 0,001 \% ; 0,003 \% ; 0,005 \%$. Kemasaman gambut sangat mempengaruhi keberadaan mikroorganisme sehingga sangat mempengaruhi proses dekomposisi bahan organik. Jadi pemberian kapur meningkatkan $\mathrm{pH}, \mathrm{Ca}$ dan $\mathrm{Mg}$ serta meningkatkan aktifitas mikroorganisme yang dapat mendekomposisi bahan organik sehingga meningkatkan kadar sulfur. Jumlah $\mathrm{S}$ pada tanah gambut yang dihasilkan tergantung kondisi $\mathrm{pH}, \mathrm{Eh}$, konsertrasi sulfat $\left(\mathrm{SO}_{4}^{-}\right)$dan kehadiran ion $\mathrm{Fe}^{+3}$ dan oksidasi sulfur (oksidasi sulfur dilakukan oleh bakteri Thiobacillus (Cohen et al, 1983).

Tabel 2 menunjukkan bahwa terjadi peningkatan nilai KTK tanah gambut seiring dengan dilakukannya penambahan takaran dolomit sebesar 2,5 ton/Ha; 5 ton/Ha; 7,5 ton/Ha dan 10 ton/Ha. Jika dibandingkan dengan tanpa perlakuan (0 ton/Ha) sebesar 4,2 me/100 g; 7,7 me/100 g; 8,22 me/100 g; 9,67 me/100 g. Adanya peningkatan nilai KTK pada tanah gambut diduga karena penambahan dolomit yang mengandung kation-kation basa yang tinggi seperti $\mathrm{CaO}$ sebanyak 35,7 $\%$ dan $\mathrm{MgO} 16,7 \%$, dimana semakin tinggi takaran dolomit, menyebabkan $\mathrm{pH}$ meningkat sehingga terjadi disosiasi gugus fungsional karbosilat $(-\mathrm{COOH})$ pada $\mathrm{pKa} 5$ dan OH-fenolat pada $\mathrm{pKa} 10$ yang mengakibatkan meningkatnya muatan negatif tanah gambut.

\section{Analisis Tanaman}

Tabel 3 menunjukkan bahwa terjadi peningkatan tinggi tanaman bawang merah seiring dengan dilakukannya penambahan takaran dolomit sebesar 2,5 ton/Ha; 5 ton/Ha; 7,5 ton/Ha dan 10 ton/Ha. Jika dibandingkan dengan tanpa perlakuan (0 ton/Ha) sebesar $15,53 \mathrm{~cm} ; 20,53 \mathrm{~cm} ; 21,36 \mathrm{~cm} ; 22,63 \mathrm{~cm}$. Berdasarkan hasil yang didapatkan, bahwa tinggi tanaman bawang merah pada tanah gambut setelah pemberian dolomit, lebih tinggi daripada deskripsi bawang merah varietas Bima Brebes. Tinggi tanaman yang melebihi tidak sebanding dengan anakan yang didapatkan.

Tabel 3. Pengaruh pemberian dolomit terhadap tinggi tanaman bawang merah (hari ke 45 ) pada tanah gambut

\begin{tabular}{cc}
\hline $\begin{array}{c}\text { Takaran Dolomit } \\
(\mathrm{cm})\end{array}$ & Tinggi Tanaman \\
ton/Ha \\
\hline 0 & $18,97 \mathrm{a}$ \\
5 & $34,50 \mathrm{~b}$ \\
7,5 & $39,50 \mathrm{c}$ \\
10 & $40,33 \mathrm{c}$ \\
\end{tabular}

Keterangan : Angka yang diikuti dengan huruf kecil yang sama berbeda tidak nyata pada taraf $5 \%$ uji Duncan (DNMRT) 
Adanya peningkatan tinggi tanaman yang terjadi diduga karena pemberian dolomit yang mampu meningkatkan $\mathrm{pH}$ tanah gambut (Tabel 2) dan menyediakan unsur hara dalam tanah serta mengandung berbagai kationkation atau unsur míkro lainnya, sehingga dapat mendukung pertumbuhan dan perkembangan tanaman bawang merah. Menurut Marsono dan Paulus (2005), pemberian pupuk yang tepat akan mampu menyediakan unsur hara bagi tanaman, mencegah kehilangan unsur hara di dalam tanah dan membantu penyerapan unsur hara.

Berdasarkan hasil analisis sidik ragam menunjukkan bahwa pengaruh pemberian dolomit pada tanah gambut yang sudah dikeringanginkan setelah masa inkubasi selama 2 minggu berbeda nyata terhadap berat basah maupun berat kering tanaman bawang merah. Begitupun dengan berat basah maupun berat kering umbi bawang merah bahwa pemberian dolomit berpengaruh berbeda nyata terhadap kedua parameter tersebut. Data hasil uji lanjut DNMRT 5\% dapat dilihat pada Tabel 4.
Tabel 4 menunjukkan bahwa terjadi peningkatan berat basah tanaman bawang merah seiring dengan dilakukannya penambahan takaran dolomit sebesar 2,5 ton/Ha; 5 ton/Ha; 7,5 ton/Ha dan 10 ton/Ha. Jika dibandingkan dengan tanpa perlakuan (0 ton/Ha) peningkatan yang terjadi sebesar 9,66 g; 22,66 g; 37,41 g; 43,14 g. Selain itu, Tabel 4 juga menunjukkan bahwa terjadi peningkatan berat kering tanaman bawang merah seiring dengan dilakukannya penambahan takaran dolomit sebesar 2,5 ton/Ha; 5 ton/Ha; 7,5 ton/Ha dan 10 ton/Ha. Begitupun, jika dibandingkan dengan tanpa perlakuan $(0$ ton/Ha) peningkatan yang terjadi sebesar $0,79 \mathrm{~g} ; 1,92 \mathrm{~g} ; 2,52 \mathrm{~g} ; 2,89 \mathrm{~g}$.

Adanya peningkatan berat basah maupun berat kering tanaman bawang merah diduga karena meningkatnya ketersediaan unsur hara akibat pemberian dolomit. Semakin tinggi dosis yang diberikan maka semakin semakin banyak unsur hara yang yang tersedia dalam tanah gambut bagi tanaman yang kemudian digunakan dalam proses metabolisme dan fisiologis tanaman, sehingga dapat meningkatkan berat kering maupun berat basah bawang merah.

Tabel 4 . Pengaruh pemberian dolomit terhadap berat tanaman dan berat umbi tanaman bawang merah pada tanah gambut

\begin{tabular}{cccccc}
\hline $\begin{array}{c}\text { Takaran } \\
\text { Dolomit } \\
(\mathrm{cm})\end{array}$ & $\begin{array}{c}\text { Berat Segar } \\
\text { Tanaman } \\
(\mathrm{g})\end{array}$ & $\begin{array}{c}\text { Berat Kering } \\
\text { Tanaman } \\
(\mathrm{g})\end{array}$ & $\begin{array}{c}\text { Berat Segar } \\
\text { Umbi } \\
(\mathrm{g})\end{array}$ & $\begin{array}{c}\text { Berat Kering } \\
\text { Umbi } \\
(\mathrm{g})\end{array}$ & $\begin{array}{c}\text { Diameter } \\
\text { Umbi } \\
(\mathrm{cm})\end{array}$ \\
\hline 0 & $1,54 \mathrm{a}$ & $0,23 \mathrm{a}$ & $0,00 \mathrm{a}$ & $0,00 \mathrm{a}$ & $0,00 \mathrm{a}$ \\
2,5 & $11,20 \mathrm{~b}$ & $1,02 \mathrm{~b}$ & $6,81 \mathrm{~b}$ & $0,59 \mathrm{~b}$ & $1,46 \mathrm{~b}$ \\
5 & $24,20 \mathrm{c}$ & $2,15 \mathrm{c}$ & $9,50 \mathrm{c}$ & $0,78 \mathrm{c}$ & $1,49 \mathrm{bc}$ \\
7,5 & $38,95 \mathrm{~d}$ & $2,75 \mathrm{~cd}$ & $15,54 \mathrm{~d}$ & $1,23 \mathrm{~d}$ & $1,83 \mathrm{bc}$ \\
10 & $44,68 \mathrm{~d}$ & $3,12 \mathrm{~d}$ & $21,92 \mathrm{~d}$ & $1,44 \mathrm{~d}$ & $2,00 \mathrm{c}$ \\
\hline & $\mathrm{KK}=24,30 \%$ & $\mathrm{KK}=33,73 \%$ & $\mathrm{KK}=28,36 \%$ & $\mathrm{KK}=42,82 \%$ & $\mathrm{KK}=30,35 \%$ \\
\hline
\end{tabular}

Keterangan : Angka yang diikuti dengan huruf kecil yang sama berbeda tidak nyata pada taraf 5\% uji Duncan (DNMRT)

Pertumbuhan dan perkembangan tanaman bawang merah dipengaruhi oleh kemasaman tanah $(\mathrm{pH})$, suhu, serta ketersediaan unsur hara (seperti $\mathrm{K}, \mathrm{Ca}, \mathrm{Mg}$ ) dalam tanah. Penambahan dolomit pada tanah gambut dapat meningkatkan $\mathrm{pH}$ (Tabel 2) yang mendukung pertumbuhan dan perkembangan bawang merah, serta meningkatkan ketersediaan hara dalam tanah seperti, $\mathrm{K}, \mathrm{Ca}$ dan $\mathrm{Mg}$ serta 
ketersediaan P. Unsur-unsur hara tersebut digunakan oleh tanaman bawang merah dalam proses metabolisme seperti pembentukan umbi, pembentukan klorofil, pembentukan tunas dan lain sebagainya. Proses metabolisme dalam tubuh tanaman akan berjalan baik apabila kebutuhan unsur haranya terpenuhi dan tersedia pada tanah.

Selain dari aspek unsur hara, diasumsikan lingkungan sekitar juga berpengaruh terhadap pertumbuhan dan perkembangan tanaman bawang merah seperti suhu, curah hujan, dan cahaya matahari. Kondisi lingkungan yang sesuai dengan syarat tumbuh tanaman tersebut dapat mendukung pertumbuhan tanaman bawang merah baik dalam proses fisiologis maupun metabolisme. Berdasarkan pendapat Nazaruddin (1989) tanaman bawang dapat tumbuh dan ditanam pada daerah dataran rendah $\mathrm{pH} 5,6-6,5$, curah hujan sekitar 300-2500 mm/tahun dan intensitas sinar matahari yang cukup.

Tabel 4 menunjukkan bahwa terjadi peningkatan berat basah umbi bawang merah seiring dengan dilakukannya penambahan takaran dolomit sebesar 2,5 ton/Ha; 5 ton/Ha; 7,5 ton/Ha dan 10 ton/Ha. Jika dibandingkan dengan tanpa perlakuan $(0$ ton/Ha $)$ peningkatan yang terjadi sebesar 6,81 g; 9,50 g; 15,54 g; 21,92 g. Selain itu, Tabel 4 juga menunjukkan bahwa terjadi peningkatan berat kering umbi bawang merah seiring dengan dilakukannya penambahan takaran dolomit sebesar 2,5 ton/Ha; 5 ton/Ha; 7,5 ton/Ha dan 10 ton/Ha. Begitupun, jika dibandingkan dengan tanpa perlakuan (0 ton/Ha) tetapi pada perlakuan 7,5 ton/Ha tidak berbeda nyata terhadap pemberian 10 ton/Ha, peningkatan yang terjadi sebesar 0,59 $\mathrm{g} ; 0,78 \mathrm{~g} ; 1,23 \mathrm{~g} ; 1,44 \mathrm{~g}$.

Dari hasil yang didapatkan, secara statistik pemberian dolomit 10 ton/Ha, dapat meningkatkan bobot kering tanaman bawang merah. Namun, dibandingkan dengan deskripsi bawang merah, hasil bobot tanaman bawang merah belum sesuai. Pada pemberian dolomit 10 ton/Ha bobot kering bawang merah mencapai 5,75 ton/ Ha, sedangkan hasil yang diinginkan sebesar 9,9 ton/Ha. Maka dari itu, perlunya peningkatan pemberian dolomit terhadap gambut untuk mencapai hasil yang maksimal umbi kering bawang merah sebesar 9,9 ton/Ha untuk varietas Bima Brebes.

Peningkatan bobot segar maupun bobot kering umbi bawang merah diduga karena dolomit yang merupakan bahan amelioran tanah mampu meingkatkan $\mathrm{pH}$ tanah (Tabel 2) yang optimal untuk pertumbuhan umbi bawang merah serta mampu menyediakan unsur hara seperti unsur $\mathrm{K}, \mathrm{Ca}$, dan $\mathrm{Mg}$ yang dibutuhkan tanaman bawang merah. Meningkatnya $\mathrm{pH}$ pada tanah gambut serta meningkatkan aktifitas mikroorganisme yang diasumsikan akan mempercepat laju dekomposisi bahan organik pada tanah gambut sehingga unsur hara cepat tersedia bagi tanaman bawang merah.

Tabel 4 menunjukkan bahwa terjadi peningkatan diameter umbi bawang merah seiring dengan dilakukannya penambahan takaran dolomit sebesar 2,5 ton/Ha; 5 ton/Ha; 7,5 ton/Ha dan 10 ton/Ha. Jika dibandingkan dengan tanpa perlakuan (0 ton/Ha) sebesar $1,46 \mathrm{~cm} ; 1,49 \mathrm{~cm} ; 1,83 \mathrm{~cm}$; $2,00 \mathrm{~cm}$. Pembentukan umbi bawang merah dipengaruhi oleh $\mathrm{pH}$ tanah gambut dan ketersediaan unsur hara yang berasal dari dolomit, dimana unsur kalium yang berasal dari dolomit berperan dalam proses tersebut. Semakin tinggi dolomit yang diberikan maka semakin banyak unsur hara yang tersedia bagi tanaman. Menurut Lakitan (2011), unsur kalium berperan meningkatkan aktivitas fotosintesis sehingga akumulasi fotosintat dapat ditranslokasikan ke organ-organ generatif khususnya umbi bawang merah. Semakin banyak bahan asimilat yang dihasilkan maka semakin banyak yang ditranslokasikan ke dalam umbi bawang merah.

Tabel 5 menunjukkan bahwa terjadi peningkatan kadar $\mathrm{S}$ pada bawang merah seiring dengan dilakukannya penambahan takaran dolomit sebesar 2,5 ton/Ha; 5 ton/Ha; 
7,5 ton/Ha dan 10 ton/Ha. Jika dibandingkan dengan tanpa perlakuan (0 ton/Ha) sebesar
$0.024 \% ; 0,024 \% ; 0,027 \% ; 0,031 \%$.

Tabel 11. Pengaruh pemberian dolomit terhadap kadar S pada tanaman bawang merah

\begin{tabular}{cc}
\hline Takaran Dolomit & Kadar S Tanaman \\
$(\mathrm{cm})$ & $(\%)$ \\
\hline 0 & $0,00 \mathrm{a}$ \\
2,5 & $0,024 \mathrm{~b}$ \\
5 & $0,024 \mathrm{~b}$ \\
7,5 & $0,027 \mathrm{c}$ \\
10 & $0,031 \mathrm{~d}$ \\
\hline & $\mathrm{KK}=15,93 \%$ \\
\hline
\end{tabular}

Keterangan : Angka yang diikuti dengan huruf kecil yang sama berbeda tidak nyata pada taraf 5\% uji Duncan (DNMRT)

Sulfur dapat diserap oleh tanaman dalam bentuk sulfat $\left(\mathrm{SO}_{4}^{2-}\right)$ dan dalam bentuk gas $\mathrm{SO}_{2}$ dari udara melalui daun. Kandungan sulfat $\left(\mathrm{SO}_{4}^{2}\right)$ sebesar $65 \%$ dari total $\mathrm{S}$ dalam tanah serta fungsi utama sulfur yaitu untuk pembentukan protein (Hardjowigeno, 1987). Pemberian dolomit dapat meningkatkan $\mathrm{pH}$ tanah serta aktifitas mikroorganisme yang menyebabkan terjadinya dekomposisi bahan organik yang meghasilkan kadar S meningkat pada tanah. Meningkatnya kadar S pada tanah, maka serapan $\mathrm{S}$ pada tanaman bawang merah meningkat.

\section{KESIMPULAN}

Pemberian dolomit pada takaran 10 ton/Ha merupakan takaran optimum yang dapat memperbaiki sifat kimia tanah gambut seperti meningkatan $\mathrm{pH} \quad 1,16$ unit; peningkatan P-tersedia 5,7 ppm; meningkatan KTK 9,67 me/100 g; meningkatan $\mathrm{S}$ tanah $0,005 \%$; dan ketersediaan K-dd 0,09 me/100 g; Mg-dd 0,19 me/100 g; serta Ca-dd 0,31 me/ $100 \mathrm{~g}$ dibandingkan dengan tanah tanpa perlakuan (kontrol).

Pemberian dolomit pada takaran 10 ton/Ha dapat meningkatkan pertumbuhan serta hasil tanaman bawang merah seperti tinggi tanaman sebesar 22,63 cm ; bobot basah tanaman bawang merah sebesar $43,14 \mathrm{~g}$; bobot kering tanaman bawang merah sebesar 2,89 g; bobot segar umbi bawang merah sebesar 21,92 g; dan bobot kering umbi bawang merah sebesar 1,44 g; diameter umbi bawang merah sebesar 2,00 cm; serta kadar $\mathrm{S}$ tanaman sebesar $0,031 \%$ dibandingkan dengan tanah tanpa perlakuan (0 ton/Ha).

\section{DAFTAR PUSTAKA}

Departemen Pertanian. 2007. Prospek dan Arah Pengembangan Agribisnis Bawang Merah. Edisi Kedua. Badan Penelitian dan Pengembangan Pertanian, Departemen Pertanian. 35 hal.

Bancin, R.R. 2016. Pertumbuhan Produksi Bawang Merah di Lahan Gambut yang Diberi Amelioran dan Pupuk Nitrogen. Fakultas Universitas Pertanian Riau. Riau. JOM FAPERTA Vol. 3 No.1 Februari 2016

Djuhariningrum T, dan Rusmmadi. 2004. Penentuan kalsit dan dolomit secara kimia dalam batu gamping dari madura. Pusat Pengembangan Bahan Galian dan Geologi Nuklir-Batan.8:332334

Hardjowigeno, S. 1987. Ilmu Tanah. Mediyatama Sarana Perkasa, Jakarta. Hal 173.

Hardjowigeno, S. 1989. Sifat-Sifat Tanah Dan Potensi Tanah Gambut Sumatra Untuk Pengembangan Pertanian. Prosiding Seminar Tanah Gambut untuk Perluasan Pertanian. Fakultas Pertanian UISU, Medan. hal. 14-42. 
Lakitan, Benyamin. 1996. Dasar-Dasar Fisiologi Tumbuhan. Jakarta: PT. Radja Grafindo Persada. 203 Hal.

Luki, U. dan Abbas M.H. 1990. Potensi Tanah Gambut untuk Pengembangan Lahan Pertanian di Sumatera Barat. Dalam Proseding Seminar Tanah Gambut untuk Perluasan Pertanian. Fakultas Pertanian Universitas Islam Sumatera Utara. Medan. Hal 290-295.

Marsono dan Paulus, S. 2005. Pupuk Akar dan Jenis Aplikasi. Penebar Swadaya. Jakarta. 54 hal.

Meene., V.D. 1984. Geological Aspects of Peat Formation in The Indonesian Malyasin Lowlands. Bulletin Geological Research and Development Centre, 9, 20-31.

Nazaruddin, A. 1989. Bawang Merah : Identifikasi Usaha Tani Mengupas Tuntas Bawang Merah Sebagai Komoditas Pertanian Bernilai Ekonomi Tinggi, Dilengkapi dengan Strategi Peningkatan Kualitas dan Kuantitas. Yogyakarta : Kanisius. 45 hal.

Nurhaida. 1988. Pengapuran Tanaman Kedelai Pada Tanah Gambut. Tesis S-1. Jurusan Ilmu Tanah, Fakultas Pertanian, Universitas Sumatera Utara. Medan. 80 hal.

Prasad, R. And Power, J.F 1997. Soil Fertility Management For Sustainable Agriculture. CRCLewis Publishers. Boca Raton New York.

Prasetyo, T. B. 1996. Perilaku Asam-asam organik Meracun pada Tanah Gambut yang diberi Garam Na dan Beberapa Unsur Mikro dalam kaintannya dengan Hasil Padi. [Disertasi]. Program Pascasarjana IPB. Bogor. 190 hal.
Prasetyo, T. B. 2003. Strategi Pengembangan Lahan Gambut di Masa Datang untuk Meningkatkan Produktivitas Lahan dalam Mendukung Ketahanan Pangan Nasional. Palembang, 2-23 Mei. Palembang. Prosiding Seminar Lokarkarya Nasional. Hal 2-3.

Radjagukguk, B. 1991. Utilization and Management of Petlanda in Indonesia for Agriculture. Tropical PeatProceeding of International Symposium on Tropical Peatland Kuching 6-10 May, 21-27.

Safuan, L.O. 2002. Kendala Pertanian Lahan Kering Masam Daerah Tropika dan Cara Pengelolaannya. IPB. Bogor.

Saijo. 2016. Pengaruh Pemberian Kapur Dolomit Terhadap Hasil Tomat Pada Tanah Gambut. Universitas Muhammadiyah Palangkaraya. $10 \mathrm{Hal}$

Sajarwan, A. 2007. Kajian Karakteristik Gambut Tropika yang Dipengaruhi Oleh Jarak Dari Sungai, Ketebalan Gambut, dan Tipe Hutan Di Daerah Aliran Sungai Sebangun. Desertasi. Fakultas Pertanian, Universitas Gajah Mada, Yogyakarta. Hal.59.

Soepardi, G. 1983. Sifat dan Ciri Tanah. Departemen Ilmu-ilmu Tanah. Fakultas Pertanian IPB. Bogor. 591 hal.

Stevenson, F.J. 1982. Humus chemistry,. John Wiley \& Sons. New York. 380 p.

Takkar, P.N. 1988. Sulfur status of Indian soils. Proc. The Sulphur Institute Fertilizer Association of India Symp. Sulfur in Indian Agriculture, New Delhi, 5/1/2/1-31. 